\title{
Teaching NeuroImages: Complex bilateral corpus callosum infarction after paradoxical embolism
}

\author{
Lightning strikes twice
}

George Vasconcelos Calheiros de Oliveira Costa, MD, Mario Henrique Lazaretto Padua, MD, Sheila Cristina Ouriques Martins, MD, PhD, Juliana Avila Duarte, MD, PhD, Rosane Brondani, MD, PhD, and Andrea Garcia de Almeida, MD, PhD

Neurology ${ }^{\circledR}$ 2018;91:e1947-e1948. doi:10.1212/WNL.0000000000006505
Correspondence

Dr. Vasconcelos Calheiros de

Oliveira Costa

george_vcoc@hotmail.com

Figure 1 Complex bilateral corpus callosum infarction
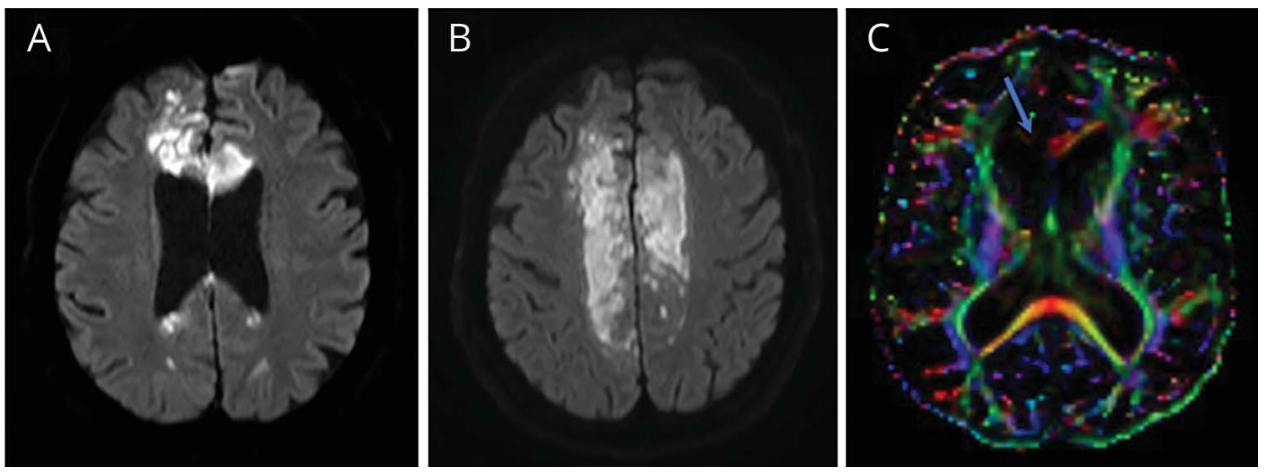

Axial diffusion-weighted images at the level of the genu and at the supraventricular level (A, B, respectively) show bilateral restricted diffusion area within anterior cerebral artery territory, including corpus callosum and other brain areas. Diffusion tensor imaging postprocessing colored map ( $C$, arrow) demonstrates reduced volume and diffusion anisotropy of callosal commissural fibers.

A 47-year-old man developed sudden-onset abulia and alien hand syndrome (AHS). MRI revealed bilateral ischemic injury within anterior cerebral artery territory (a complex bilateral corpus callosum infarction ${ }^{1}$ ) due to obstruction of a variant bihemispheric A2 branch by a thrombus (figures 1 and 2), also demonstrated on 3D volume-rendered CT angiography (figure 2). The finding of lower-limb deep venous thrombosis in a patient with right-to-left interatrial shunt accounted for the case, given workup was otherwise unremarkable.

This case is unique for paradoxical embolization of a variant artery (prevalence $2 \%-7 \%^{2}$ ) that led to a complex bilateral corpus callosum infarction presenting with AHS. ${ }^{1}$

\section{Author contributions}

G. Vasconcelos Calheiros de Oliveira Costa: concept design, elaboration and critical revision of the case report. M.H. Lazaretto Padua: elaboration and critical revision of the case report. S.C. Ouriques Martins: elaboration and critical revision of the case report for intellectual content. J.A. Duarte: image selection and critical revision of the case report for intellectual content. R. Brondani: critical revision of the case report for intellectual content. A. Garcia de Almeida: critical revision of the case report for intellectual content.

\section{MORE ONLINE}

$\rightarrow$ Teaching slides

links.lww.com/WNL/

A738

From the Departments of Neurology (G.V.C.d.O.C., M.H.L.P., S.C.O.M., R.B., A.G.d.A.), Internal Medicine (S.C.O.M.), and Radiology (J.A.D.), Hospital de Clínicas de Porto Alegre, Brazil. Go to Neurology.org/N for full disclosures. Funding information and disclosures deemed relevant by the authors, if any, are provided at the end of the article. 

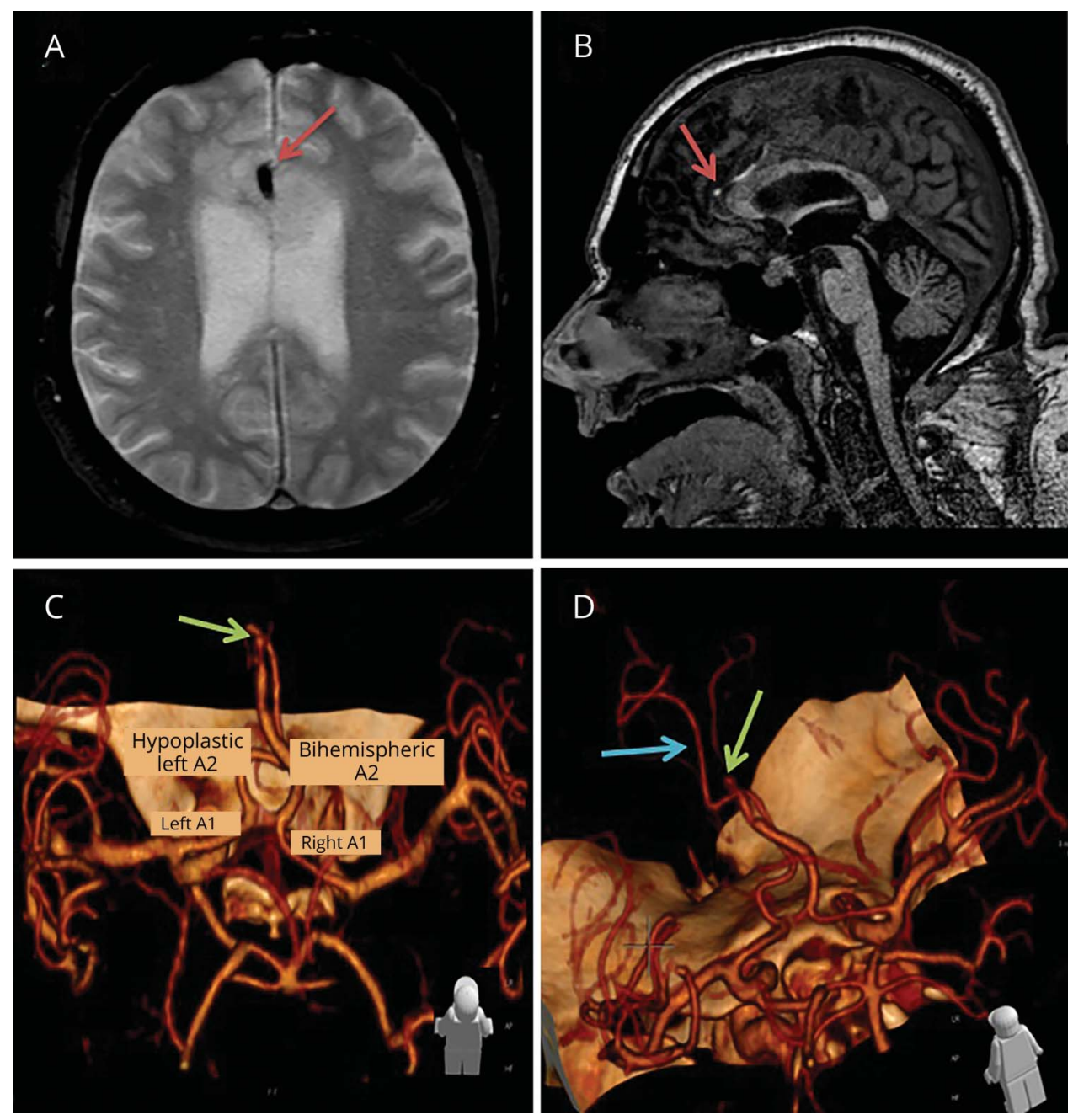

Axial gradient recalled echo $\mathrm{T}^{*}$ and sagittal T1-weighted images (A, B) reveal thrombotic occlusion of the variant right bihemispheric A2 branch (red arrows). 3D volume-rendered CT angiography also demonstrates absence of downstream blood flow (C, D, green arrows) and the hypoplastic left A2 branch (D, blue arrow)

\section{Study funding}

No targeted funding reported.

\section{Disclosure}

The authors report no disclosures relevant to the manuscript. Go to Neurology.org/N for full disclosures.

\section{References}

1. Gao X, Li B, Chu W, Sun X, Sun C. Alien hand syndrome following corpus callosum infarction: a case report and review of the literature. Exp Ther Med 2016;12: 2129-2135.

2. Dimmick SJ, Faulder KC. Normal variants of the cerebral circulation at multidetector CT angiography. Radiographics 2009;29:1027-1043. 


\section{Neurology}

\section{Teaching NeuroImages: Complex bilateral corpus callosum infarction after paradoxical embolism: Lightning strikes twice}

George Vasconcelos Calheiros de Oliveira Costa, Mario Henrique Lazaretto Padua, Sheila Cristina Ouriques Martins, et al.

Neurology 2018;91;e1947-e1948

DOI 10.1212/WNL.0000000000006505

\section{This information is current as of November 12, 2018}

\section{Updated Information \&} Services

References

Subspecialty Collections

Permissions \& Licensing

Reprints including high resolution figures, can be found at: http://n.neurology.org/content/91/20/e1947.full

This article cites 2 articles, 0 of which you can access for free at: http://n.neurology.org/content/91/20/e1947.full\#ref-list-1

This article, along with others on similar topics, appears in the following collection(s):

All Cerebrovascular disease/Stroke

http://n.neurology.org/cgi/collection/all_cerebrovascular_disease_strok

Embolism

http://n.neurology.org/cgi/collection/embolism

Infarction

http://n.neurology.org/cgi/collection/infarction MRI

http://n.neurology.org/cgi/collection/mri

Information about reproducing this article in parts (figures,tables) or in its entirety can be found online at:

http://www.neurology.org/about/about_the_journal\#permissions

Information about ordering reprints can be found online:

http://n.neurology.org/subscribers/advertise

Neurology ${ }^{\circledR}$ is the official journal of the American Academy of Neurology. Published continuously since 1951, it is now a weekly with 48 issues per year. Copyright @ 2018 American Academy of Neurology. All rights reserved. Print ISSN: 0028-3878. Online ISSN: 1526-632X.

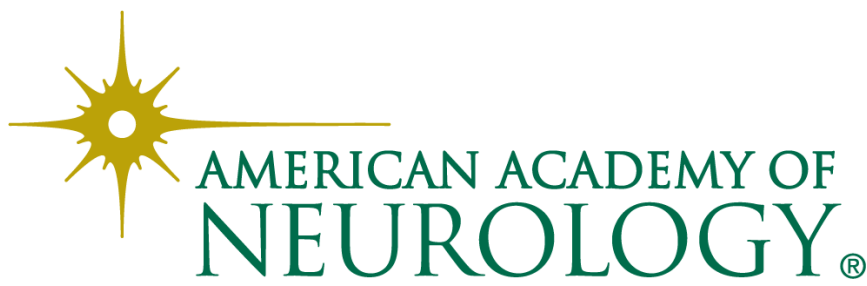

